\title{
The Trade and Environment Debate: THE NORMATIVE AND INSTITUTIONAL INCONGRUITY
}

\author{
Simeneh Kiros Assefa *
}

\section{Introduction}

Although human activities are in general said to be responsible for environmental problems, trade takes the lion's share. The ever growing production and consumption of goods and services, the major inputs of which are natural resources, discharge of wastes and dangerous chemicals into the environment, etc. have always been major concerns. The reality has thus provoked the discussion over global concerns regarding trade related environmental issues within the UN as well as in the GATT/WTO regimes.

Although national economic self-interest and international relations dominate the trade and environment debate, there are three important convoluted factors that need to be dispelled. First, the GATT/WTO is an exclusively trade organisation that is not necessarily competent to address environmental concerns except that the GATT Art XX addresses the General Exception on human, animal and plant life and health. Second, although trade is the major category of human activity as a source of environmental problems, there are wide range of Multilateral Environmental Agreements ("MEAs") negotiated and agreed upon outside the purview of trade institutions. And third, many of those MEAs are administered by various secretariats other than the United Nations Environmental Program ("UNEP") or the GATT/WTO.

Many of the environment-related trade disputes are, however, raised under GATT XX and entertained by the dispute settlement bodies of the GATT/ WTO with significant ramifications for concerns of the environment and the normative and institutional frameworks of the UNEP and others in this realm. This shows institutional gaps regarding the issue of trade and environment, and in effect, nations are dealing with the problem by local legislation with extra-jurisdictional trade ramifications.

This article examines the convergence of trade and environmental issues and the divergence of their enforcement because of the institutional competition

* LL. B (Addis Ababa University, 1998), LL. M. (University of Pretoria, 2002), LL. M. (Kyushu University, 2006), LL. M (University of San Francisco, 2008) 
between GATT/WTO and UN and the normative incongruity between the GATT and MEAs. In so doing, emphasis is placed on the various environment related trade disputes, environment related provisions of the WTO and the various Dispute Settlement Bodies, with a view to assessing the effectiveness of the existing environmental protection approach. Section 1 discusses the trade-environment debate (both institutionally and normatively) through time and gives background of the problem; Section 2 deals with the various environment related provisions of the WTO; and Section 3 highlights the various GATT Article XX disputes. Interpretation of the provision of GATT Article XX and its relation with MEAs are briefly discussed under Section 4 which is followed by concluding remarks.

\section{Background to the Trade-Environment Debate}

The issue of environment was a major concern in Europe since early 1950s. ${ }^{1}$ Europe was dealing with the environment within the Economic Commission for Europe (ECE) system but, as the problem had already got out of hand, it was tabled before the UN by Sweden in $1968 .^{2}$ Although there was a debate whether the UN is a proper forum for environmental issues, the first world conference on Human Environment was held in 1972 in Stockholm. ${ }^{3}$

In preparation for the conference, UN was gathering public opinion in different countries and international and regional institutions; one of such institutions was the GATT. ${ }^{4}$ This was the apparent impetus for the environmental issues to be formally raised in the GATT Council of Representatives ("the Council"), the highest decision making body of the GATT. In the same session, in 1971, the Council established the Group on Environmental Measures in International Trade (EMIT) which is to be convened only at the request of Contracting Parties. ${ }^{5}$ The following year, the first conference on the environ-

1 A. Bishop and R. Munro, "The UN Regional Economic Commission and Environmental Problems" in 26 International Organization No 2 (1972) p 359

2 R. Gardner "The Role of the UN in Environmental Problems" in 26 International Organization No 2 (1972) p 237

3 See infra note 31 for the impropriety of the UN for environmental issues.

${ }^{4} \mathrm{We}$ need to appreciate the positive contributions of the GATT. While the UN was in preparation of the world conference on human environment, the GATT was requested to make a contribution as a con- sequence of which the Secretariat made a research on "Industrial Pollution Control and International Trade" Early Years: emerging environment debate in GATT/ $W T O<$ www.wto.org $>$ (last accessed on December 2, 2007). Information from states and international organizations were gathered through, for instance, the specialized agencies of the $\mathrm{UN}$ in the regional offices. See generally Bishop and Munro Supra note 1 as they discuss the role of regional economic commissions (ECAFA, ECA, CWLA and ECE) in the dialogue on environmental issues. 
ment under the auspices of the UN was held in Stockholm. With respect to the EMIT, on the other hand, there was a long period of silence in the trading world until 1991. The first meeting of the EMIT, the long-dormant Group as referred to by the Group itself, was convened in $1991 . .^{6}$ In the same year, a dispute arose between Mexico and the United States when the latter banned imports of tuna from Mexico on the ground of environmental protection. ${ }^{7}$

In 1992 the United Nations Conference on Environment and Development, usually known as the Earth Summit, was held in Rio de Janeiro. The Program of Action which was adopted at the Rio Conference is referred to as Agenda 21 which meant the Agenda for the $21^{\text {st }}$ Century. It focused on the link between sustainable development and environmental protection. ${ }^{8}$ One can easily sense that the Rio Earth Summit has significantly impacted the Uruguay round of GATT negotiations.

A paragraph is thus included on environment and sustainable development in the Preamble of the WTO ${ }^{*}$ contrary to what was the case in the GATT ' 47

5 Trade and Environment Division - World Trade Organization, Trade and Environment at the WTO p 2. <http:/

www.wto.org/english/tratop e/envir e/ envir_wto2004_e.pdf $>$ (last accessed on December 2, 2007).

6 Id. $\mathrm{p}$ 4; also see the "REPORT OF THE MEETING OF THE GROUP ON ENVIRONMENTAL MEASURES AND INTERNATIONAL TRADE" (27 November 1991), para 2. The EMIT has never been convened between 1971 and 1991 while there were two rounds of trade negotiations during this period. The Tokyo round was held between 1973 and 1979 and the major part of the Uruguay round had been undertaken during this period.

7 This case is discussed in greater detail later in this essay

8 Trade \& Environment Division Supra note 5 at 4

9 Recognizing that their relations in the field of trade and economic endeavour should be conducted with a view to raising standards of living, ensuring full employment and a large and steadily growing volume of real income and effective demand, and expanding the production and trade in goods and services, while allowing for the optimal use of the world's resources in accordance with the objective of sustainable development, seeking both to protect and preserve the environment and enhance the means for doing so in a manner consistent with their respective needs and concerns at different levels of economic development... WTO Charter Preamble, paragraph 1.

10 Recognizing that their relations in the field of trade and economic endeavour should be conducted with a view to raising standards of living, ensuring full employment and a large and steadily growing volume of real income and effective demand, developing the full use of the resources of the world and expanding the production and exchange of goods. ,Being desirous of contributing to these objectives by entering into reciprocal and mutually advantageous arrangements directed to the substantial reduction of tariffs and other barriers to trade and to the elimination of discriminatory treatment in international commerce... 
Preamble. ${ }^{10}$ Later, the Committee on Trade and Environment ("CTE") was also established within the GATT/WTO system in 1994 replacing the EMIT. ${ }^{11}$

The longstanding question is whether (the GATT 12 and now) the WTO, having seen its responsibilities as are provided for in the establishing Charter 13 and its commitment as tested though time, is the right forum in addressing the issue. Some of the complaints are based on the presumption that the WTO is not environment friendly. ${ }^{14}$ It is true that the GATT was negotiated at the time where economic development and full employment were the sole concerns while the environment was not quite so. ${ }^{15}$ This can be gathered both

${ }^{11}$ Ministerial Decision on Trade and Environment, 14 April 1944, 33 ILM 1267 (1994)

12 World War II is said to be the result of the serious global economic recession preceding it by the race to bottom depreciation of currencies with a view to sell one's commodities. It is true that the war itself resulted in serious destruction that has never been seen. The creation of the GATT as part of the Bretton Woods institutions, (the International Monetary Fund (IMF) and World Bank for Reconstruction and Development (IBRD), is thus to address such global economic crisis by elimination of border restrictions be it tariff or quantitative, and other domestic restriction on foreign commodities.

${ }^{13}$ Art III - Functions of the WTO

1. The WTO shall facilitate the implementation, administration, operation, and further the objectives, of this Agreement and of the Multilateral Trade Agreements, and shall also provide the framework for the implementation, administration and operation of the Plurilateral Trade Agreements.

2. The WTO shall provide the forum for negotiations among its Members concerning their multilateral trade relations in matters dealt with under the agreements in the annexes to this Agreement. The WTO may also provide a forum for further negotiations among its Members concerning their multilateral trade relations, and a framework for the implementation of the results of such negotiations, as may be decided by the Ministerial Conference.

3. The WTO shall administer the Understanding on Rules and Procedures Governing the Settlement of Disputes in Annex 2 to this Agreement.

4. The WTO shall administer the Trade Policy Review Mechanism provided for in Annex 3 to this Agreement.

5. With a view to achieving greater coherence in global economic policy-making, the WTO shall cooperate, as appropriate, with the International Monetary Fund and with the International Bank for Reconstruction and Development and its affiliated agencies.

14 Particularly with respect to the interpretations of the provisions of GATT Art XX it is contended that members of the Panel and the $\mathrm{AB}$ do not have environmental and other (background) social issues coming up with trade-biased interpretation those provisions which are already restricted in wording. F. Macmillan WTO and the Environment (Sweet and Maxwell, 2001) pp 8, 9. 
from the Preamble of GATT 1947 and the then existing circumstances. ${ }^{15} 16$ It is understandable for government representatives of the day to focus on the calling of the time. It is not, however, the sole reason for the GATT/WTO to deal less with the environment than it should, at least by way of reconsideration as in the case of other issues.

These developed nations were said to be not committed to addressing environmental issues for there has been, as always, national economic selfinterest. ${ }^{17}$ Thus, environmental issues were only addressed on ad hoc basis such as by the creation of Committee on Challenges to Modern Society (CCMS) under the NATO, ${ }^{18}$ or by establishing a body called Senior Advisors to the ECE. 19

In subsequent efforts for the establishment of a permanent body on the issue of environment, there is a serious competition of institutions apparently between the UN and other institutions. ${ }^{20}$ Appended to it is the issue whether developing nations should participate in the discussion either because it does not concern them ${ }^{21}$ or the process delays immediate and technical measures needed immediately. ${ }^{22}$ Further study indicated that, environmental problems are concerns of the poor in as much as they are of the affluent. ${ }^{23}$

15 This Agreement is the result of discussion between the US and the UK; Western Europe had not recovered from the ravages of the war and common market was not established; Japan was essentially outside of the international economy; and most African and Asian countries were under colony. A. Lowenfeld, International Economic Law (Oxford: Oxford University Press, 2002) pp 23, 45; the developing countries expressed this in the UN Declaration on New International Economic Order, para 1.

16 Supra note 10

17 It is indicated that there was even less positive attitude on the part of governments, the public and corporations, as well as less commitment on the part of environmental scientists. B. Johnson “The United Nation's Institutional Response to Stockholm: A Case Study in the International Politics of Institutional Change" in 26 International Organization No 2 (1972) p 264

${ }^{18}$ Id. p 262

${ }^{19}$ Bishop and Munro Supra note 1 at 366

20 Those other competing institutions where the developed countries have influence on the outcome of the case either by virtue of weighted vote, restrictive membership or otherwise, , depending on the nature of the issue, could be such as GATT, OECD and NATO.

21 G. Kennan for instance, opined that "the United Nations is not the proper forum for dealing with the environmental problems because these problems were mainly caused by ten of the world's more industrialized countries" To Prevent a World Wasteland: A proposal, 48 Foreign Affairs No 3 (1970) pp 410-11. Also, L. Engfeldt, "The United Nations and the Human Environment - Some Experiences" in 27International Organization No 3 (1973) p 396; Gardner Supra note 2. 
It is always the case in international relations that states disagree on institutions where a particular issue is to be disposed of based on where they think they have influence on the outcome of the case. In the early days of the cold war, this was strengthened not only by the already formed bloc, the east and west divide, but it was also affected by the growing north and south divide. 222324 The UN General Assembly was perceived to be more of an organization of the weak conglomerate. This is particularly so when the newly independent African and Asian countries became members of the UN thereby forming a significant number. ${ }^{25}$

Many developed countries were not willing to address issues within the UN system, where, with equality of votes, they could not have control over the outcome of cases $^{26}$ Matters of trade and development could be good examples. When issues of trade and development could not be addressed within the GATT system, ${ }^{27}$ a group of developing countries tabled them before the UN, while developed countries proposed that such matters could be addressed within the GATT, IMF/WB regimes. ${ }^{28}$ Yet, the UN formed UNCTAD and declared the 1960s as the first development decade, among others,

22 Many wrongly blamed the developing countries for being ignorant and for their lack of will to participate in the negotiation, Engfeldt Supra note 21 p 394. Their participation is said to have been obtained with a cost "...first it did require an immense amount of the time of the secretariat.Second, the secretariat has encouraged the developing states to believe that concern with development will not reduce the funds available for development but rather will increase them". D. Kay and E. Skolnikoff "International Institutions and the Environmental Crisis: A Look Ahead' in 26 International Organization No 2 (1972) p 475. Some call the conference the environmental bandwagon as a vehicle for more financial assistance from the industrialized countries. Engfeldt Supra note 21 at 396

23 M. Strong "The United Nations and the Environment" in 26 International Organization No 2 (172) p 169; Engfeldt Supra note 21 at 402. See also Schultz, Infra note 49.

24 See generally Kay and Skolnikoff Supra note 22; S. Weintraub "How the UN
Votes on Economic Issues" in 53 International Affairs No 2 (1977); S. Zamora "Voting in International Organizations" in 74 American Journal of International Law No 3 (1980) $25_{I d}$

26 Id. Also see, for instance, B. Gossovic and J. Ruggie, "On the Creation of a New International Economic Order: Issue Linkage and the Seventh Special Session on the UN General Assembly" in 30 International Organization No 2 (1976); H. W. Singer "The New International Economic Order: An Overview" in 16 The Journal of Modern African Studies No 4 (1978). The US, in fact, made the UN particularly some of its organs wherein it does not have much control, made irrelevant focusing its effort in the IMF, IBRD, GATT, OECD and NATO. See S. Finger "United States Policy toward International Institutions" in 30 International Organizations No 2 (1976); S. Weintraub "What do We Want from the United Nations" in 30 International Organization No 4 (1976). 
despite the disagreement of the developed countries. ${ }^{27} 2829$ In response to these activities, developed countries conceded to include Part IV of the GATT relating to trade and development to indicate that the subject can better be addressed within the GATT system than through the UN. As it stands now, UNCTAD seems to have been made a powerless organization to address trade issues of the developing countries. ${ }^{30}$

The fate of the issue of environment and trade appears to be similar. When the issue of environment was tabled before the UN, there was a debate whether the UN is the right organ to deal with the matter. ${ }^{31}$ In fact, when such social issues such as trade, development and environment are raised, it was considered as the political issue of the communist against free trade. ${ }^{32}$ It is easily discernible that there was an effort to move the issue out of the UN to other organs such as the GATT where the developed countries have control of the outcome.

27 Even though a few developing countries participated in the making of the GATT it is believed to be the club of the rich. At least at the initial stage there were only 13 developing countries represented and two of those from Africa were not represented by a representative of their government. Both South Africa and Rhodesia (currently referred to as Zimbabwe) were represented by a colonialist rule which owns the industries in those countries. Also see note 15 above.

28 Within the GATT system always, the West has the upper hand because as the two institutions both the IMF and WB have weighted voting procedure, it is very unlikely that the agenda of the developing countries could be promoted. See for example S. Zamora "Voting in Economic Institutions" 74 American Journal of International Law No 3 (1980)

29 R. Gardner "The United Nations Conference on Trade and Development" in 22 International Organizations No 1 (1968) p 106

30 UNCTAD was created in order to maintain the net flow of long term capital to developing countries and to improve its terms and conditions as a reaction to the drop of prices of primary commodities and worsening in the terms of trade. S. Metsger "Development in the Law and Institutions of International Economic Relations: UNCTAD" in 61 American Journal of International Law No 3 (1986) p 758; after many decades of development, those developing countries could not record any significant development. Some are even under a new classification called Least Developed being worse off than they were by the time UNCTAD was initiated and created. See generally R. Green "UNCTAD and After: The Anatomy of a Failure" in 5 Journal of Modern African Studies No 2 (1967)

31 Some considered the UN structure and procedure itself to be an impediment because it is obsolete (Engfeldt Supra note 21 at 394, 395) for such technical issues where swift and efficient action is needed on such issues like the environment; still others consider taking an issue before the UN is doomed to futility (Johnson Supra note 17 at 262). 
This can be gathered from the patterns of certain measures within the GATT . The inclusion of Part IV in the GATT was used not to complement and reinforce, but rather to weaken the efforts of UNCTAD in addressing trade and development issues of the developing countries. When the preparation for the first conference on the Human Environment was in progress, the GATT Council was convened. While the preparation for the Rio Earth Summit was underway, the EMIT convened for the first time in 1991 in preparation for the same. ${ }^{32}{ }^{33}$ In response to the Rio Summit, the Preamble of the WTO Charter contains a statement on sustainable development. ${ }^{34}$ However, there does not seem to be consistent actions on the part of GATT/WTO because some of them are positive reactions while others are not.

On the other hand, the UNEP is established as a weaker environmental arm of the UN, ${ }^{35}$ with jurisdictional ${ }^{36}$ and budgetary limitations ${ }^{37}$ Moreover, a

32 This is particularly so seen in the overreactions to the negotiation on the law of the sea and environmental conferences because previously those matters of the environment which were outside national territories and jurisdictions were declared to be common heritage of mankind in the UN Charter of Economic Rights and Duties of States Resolution during the establishment of the New International Economic Order. G. Melloan "Global View: Flying Down to Rio, for Fun and Profit" Wall Street Journal (Monday, May 11, 1992) D. Bandow "Deep-Six the Law of the Sea" Wall Street Journal (Thursday, July 28, 1998).

33 Trade and Environment Division - WTO Supra note 5 at 4

${ }^{34}$ Supra note 9

35 Institutional and financial arrangement for international environmental cooperation UN General Assembly Resolution 2997 (XXVTTT); The organizational structure of the UNEP is that, there is the Governing Council, as the highest decision making body, is composed of 58 countries (Id. Section TT Para 3); the work is to be undertaken by the Environmental Coordination Board which meets periodically under the chairmanship of the Executive Director who is also the head of the small secretariat. The Environment Coordination Board reports to the Governing Council. The latter reports to the ECOSOC which in turn reports to the General Assembly (Id. Section TV Para 2, and Section T Para 3)

36 The readings of the powers and functions of the Governing Council (Id. Section T Para 2), or the Executive Director (Id. Section TT, Para 2) or that of the Environment Coordination Board (Id. Section TV Para 2) do not indicate any substantive power to the UNEP. The tasks of UNEP to design environmental programs and assess their implementation and effectiveness ought to be accompanied by organizational strength and resources.

37 Funding has been a point of debate before the establishment of the Program; (Engfeldt Supra note 21 at 396). Section TT Para 3 of the Establishment Resolution provides that the expenses of the Governance Council and a small secretariat are to be covered from the regular budget of the UN. Such programs that are of "general interest as regional and global monitoring, assessment and datacollecting systems, including, as appropriate costs for national counterparts; environmental research; information exchange and dissemination; public edu- ${ }^{\wedge}$ 
number of Multilateral Environmental Agreements (MEAs) have been negotiated and entered into force between the first conference on the human environment in 1972 and the Rio conference in 1992.38 At the Rio Conference various agreements were reached with respect to the normative and institutional framework of environmental issues. ${ }^{39}$ Subsequently, the Kyoto Protocol was adopted and signed by many major industrial and developing countries except the US. ${ }^{40}$ However, they are not under the administration of the UNEP. Nor is there any other single organization that has clear responsibility

cation and training; assistance for national, regional and global environmental institutions; the promotion of environmental research and studies for the development of industrial and other technologies best suited to policy of economic growth compatible with adequate environmental safeguards; and such other programs as the Governing Council may decide upon, and that in the implementation of such programs due account should be taken of the special needs of the developing countries" are to be financed from the environmental fund established by voluntary contribution of members (Id. Section III para 3).

38 Although the agreements are based on diverse issues, UNEP maintains a list of 98 MEAs and 117 regional environmental agreements negotiated since 1946, such as, Convention on the Prevention of Marine Pollution by Dumping of Wastes and other Matter (1972), Convention on International Trade in Endangered Species (International Convention for the Prevention of Pollution by Ships, 1973, as modified by the Protocol of 1978 relating thereto, Convention on the Conservation of Migratory Species of Wild Animals (1979), United Nations Convention on the Law of the Sea (1982, it is not entirely an environmental agreement, but Part XII addresses the preservation of the marine environment), Convention on the Protection of the Ozone Layer (1985), Montreal Protocol on Substances that Deplete the Ozone Layer (1987), Convention on the Control of
Transboundary Movements of Hazardous Wastes and their Disposal (1989) Multilateral Environmental Agreement Negotiator's Handbook $2^{\text {nd }}$ Ed. (University of Joensuu, 2007) p 1-3 \& 1-4. Out of these agreements 20 of them include provisions that can affect trade ("Relationship between WTO and MEA Rules" $<$ www.wto.org $>$ (last accessed on December 6, 2007)

39 The adoption of the United Nations Framework Convention on Climate Change, the Convention on Biological Diversity, the decision to negotiate the Convention to Combat Desertification, an Action Plan called "Agenda 21 " the decision to establish the Commission on Sustainable Development, The Rio Declaration composed of 27 Principles are the essential ones. "Multilateral Environmental Agreements Negotiator's Handbook', 2nd Ed (University of Joensuu, 2007) pp. 1-5

40 While the US has been the force behind the global economic growth after WWII, with respect to the issues of global environment it is shying away from ratifying various environmental treaties such as the Basel Convention and the Convention on Climate Change and on Biodiversity. The US, in fact, signed and unsigned (whatever the meaning of the word in international law) the Kyoto Protocol contending that it is fatally deficient in fundamental ways "Hot Politics" $<$ www.pbs.org $>$ (last accessed on November 6,2007$)$. It is thus on the defence seat without a clear direction while the ${ }^{\wedge}$ 
for those environmental treaties. They are rather administered through secretariats scattered around the world. ${ }^{41}$ Unlike the WTO agreement where the obligation is a single undertaking, the MEAs could be signed a la carte; countries are free to sign some and ignore others. Unsurprisingly therefore, both the UNEP and the MEAs are ineffective. Moreover, it is made clear that the GATT is not an institution with the competence to set environmental standards nor can it review environmental priorities chosen by each country. ${ }^{42}$ Yet, the relationship between the MEAs and the GATT does not seem to be clear. ${ }^{43}$

\section{Environment-related Provisions Under GATT}

The historical development of GATT/WTO is a trade liberalization effort to the benefit of developed countries. Originally the GATT 1947 and later the Agreement on Sanitary and Phytosanitary Measures (SPS Agreement) and the Agreement on Technical Barriers to Trade (TBT Agreement) made very little concession allowing member states to take domestic measures with a view to protect human, animal and plant life and health and environment. The

Europeans are shaping the agenda and imposing their regulatory style on new agreements, determined to move more firmly on restraining greenhouse gas emissions - complicating the U.S. ability to join particularly with limited domestic political interest or support. M. Kimble "Multilateral Environmental Agreements - Regulating Global Goods" in Trade and Environment, the WTO, and MEAs $<$ www.boell.org $>$ (last accessed December 6, 2007)

41 Most of the MEAs, especially the big ones negotiated in the last three decades, operate through secretariats scattered around the world rather than by UNEP.

The agreement on desertification is headquartered in Germany, on Persistent Organic Pollutants (meant to control chemicals such as dioxins, PCBs, and DDT) is in Stockholm; the Convention on Trade in Endangered Species is in Geneva, on chlorofluorocarbon control is in Quebec, Antarctic protection in Tasmania, tropical-timber control in Yokohama, and so on. Each is responsible for monitoring its' members compliance and each has its own enforcement policy.

42 Group on Environmental Measures and International Trade, "THE GATT AND the Trade Provisions of MultilatERAL ENVIRONMENTAL AgreEMENTS" Submission from The European Community (17 November 1992) para 1.2

43 in its first meeting, the Group adopted as one of its three agenda items the "trade provisions contained in existing multilateral environmental agreements (e.g. the Montreal Protocol on Substances that Deplete the Ozone Layer, the Washington Convention on international Trade in Endangered Species and the Basel Convention on the Control of Transboundary Movements of Hazardous Wastes and Their Disposal) vis-a-vis GATT principles and provisions." Group on Environmental Measures and international Trade, ' Trade Provisions Contained in Multilateral Environmental Agreements' Note by the Secretariat (Revised, 11 October 1993, hereinafter, GATT Secretariat Note i) p 2 
content of those provisions were not understood for a long time. ${ }^{44}$ Currently, there are various provisions found in five different WTO agreements: the GATT, GATS, TRIPs, TBT and SPS.

It is obvious that, because of the influence of the Rio Earth Summit, the WTO Charter recognizes the relations between trade and the environment and requires (member states) that while endeavouring "to raising standards of living, ensuring full employment and a large and steadily growing volume of real income and effective demand, and expanding the production and trade in goods and services," they need to allow "for the optimal use of the world's resources in accordance with the objective of sustainable development, seeking both to protect and preserve the environment and enhance the means for doing so in a manner consistent with their respective needs and concerns at different levels of economic development." 45

This is a vague guiding principle, in the interpretation and application of member states' rights and obligations in the GATT/WTO system. The various specific provisions found in the other agreements are thus equally important. It is necessary to begin with the provisions of the GATT for two reasons: first the GATT is the first and the original agreement in operation since 1948; second, all respondent states in those environment related trade disputes invoked the provisions of GATT Article XX as a defence. The relevant part of GATT Article XX, General Exceptions, provides that:

Subject to the requirement that such measures are not applied in a manner which would constitute a means of arbitrary or unjustifiable discrimination

44 In fact, while for instance, the provisions of GATT Art XX were there since 1948, they are invoked only in early 1990s. The EMIT, for instance, was aware neither of the scope of its obligations nor of the provisions. "One delegation stated that it did not view this Group as a negotiating forum but as a body in which to examine the interface of GATT rules and environmental concerns; this would involve technical work to which experts from capitals could provide input. Another delegation believed that the work of the Group should be conveyed to the UNCED. Another believed that there was a close link between the work of this Group and that of the Working Group on Domestically Prohibited Goods, to which this delegation attached a great deal of importance. It hoped that this Group could give new vigour to the work in the latter Working Group as it was in need of revival. Another delegation stated that the Group would enter into an entirely new area of work and therefore must proceed in a highly prudent manner. It believed that the role of the Group should be to send a positive message of the role of trade policy in environmental matters." Group on Environmental Measures and International Trade, "REPORT OF THE MEETING OF THE GROUP ON ENVIRONMENTAL MEASURES ANDINTERNATIONAL TRADE" (27 November 1991) para 6

45 Supra note 9 
between countries where the same conditions prevail, or a disguised restriction on international trade, nothing in this Agreement shall be construed to prevent the adoption or enforcement by any contracting party of measures:

(b) necessary to protect human, animal or plant life or health;

(g) relating to the conservation of exhaustible natural resources if such measures are made effective in conjunction with restrictions on domestic production or consumption...

The General Agreement on Trade in Services (GATS) contains almost identical provision under Article XIV (b) as its own general exceptions that member states may take measures "necessary to protect human, animal or plant life or health..." This provision is subject to the same restriction as in GATT Article XX because the measure is legitimate in so far as "it is not applied in a manner which would constitute a means of arbitrary or unjustifiable discrimination between countries where like conditions prevail, or a disguised restriction on trade in services." 46

The Agreement on Sanitary and Phytosanitary Measures (SPS) has by far extensive provisions accommodating human, animal and plant life and health protection with apparent significant restrictions on free trade. Thus, member states have the right to take sanitary and phytosanitary measures necessary for the protection of human, animal or plant life or health. However, such measures are subject to two requirements; first, that they are not inconsistent with the provisions of the Agreement; second, such measure is applied "only to the extent necessary to protect human, animal or plant life or health, based on scientific principles and is not maintained without sufficient scientific evidence, except as provided for in paragraph 7 of Article 5." 47

The Agreement further provides that any sanitary or phytosanitary measures establishing international standard (guideline to which member states are free to demand compliance) should be in compliance with all WTO Agreements. ${ }^{48}$ If a member state, however, sets a standard beyond the international standard,

46 The chapeau of Art XTV of GATS

47 Art 2 (1) \& (2); a more or less similar provision is contained in the Preamble (paras 1, 2); Paragraph 7 provides that "In cases where relevant scientific evidence is insufficient, a Member may provisionally adopt sanitary or phytosanitary measures on the basis of available pertinent information, including that from the relevant international organizations as well as from sanitary or phytosanitary measures applied by other Members. In such circumstances, Members shall seek to obtain the additional information necessary for a more objective assessment of risk and review the sanitary or phytosanitary measure accordingly within a reasonable period of time." 
it must show a scientific justification and that a risk assessment ought to be carried out. 49

With respect to patentable subject matters, the agreement on Trade Related aspects of Intellectual Property Rights (TRIPS) recognizes the right of member states to exclude an invention from patentability and commercial exploitation within its territory with a view to "protect 'ordre public ' or morality, including to protect human, animal or plant life or health or to avoid serious prejudice to the environment, provided that such exclusion is not made merely because the exploitation is prohibited by their law." 50

Finally, the Agreement on Technical Barriers to Trade (TBT) also recognizes the right of member states to take measures or set requirements necessary to "ensure the quality of its exports, or for the protection of human, animal or plant life or health, of the environment... at the levels it considers appropriate." 51 The agreement subjects this right, as in the chapeau of both GATT Article XX and GATS XIV, to similar restrictions that those requirements may "not be applied in a manner which would constitute a means of arbitrary or unjustifiable discrimination between countries where the same conditions prevail or a disguised restriction on international trade, and are otherwise in accordance with the provisions of the Agreement." 52 The Agreement further provides that "technical regulations shall not be more trade-restrictive than necessary to fulfil a legitimate objective, taking account of the risks nonfulfilment would create." 53

These are the major provisions, if not all, ${ }^{54}$ on trade and environment within the GATT/WTO system. These provisions are basically general exceptions, deviations from the basic principles of international trade such as the Most Favoured Nation ("MFN") and National Treatment principles, as well as a restriction to liberalized trade. As exceptions, their interpretation and applica-

${ }^{48} \operatorname{Art~3(2)}$

49 J. Schultz "The GATT/WTO Committee on Trade and the Environment - Toward Environmental Reform" in 89 The American Journal of International Law No 2 (1995) p 428

${ }_{50}^{50}$ Art 27 (2)

${ }_{52}^{51}$ Art 2.2 and para 6 of the Preamble 52 Id.

${ }^{53}$ Art 2.2. Those legitimate objectives, as provided for in the same provision and the provisions of Art 5.4 are, inter alia: national security requirements; the pre- vention of deceptive practices; protection of human health or safety, animal or plant life or health, or the environment. Such state has various other obligations when it sets such technical requirements. See the provisions of Art 2.9, 2.10, 5.4 of GATS.

54 Other provisions are not that important because they are either included only in the preamble or are mere statements in a weak agreement such as the Agreement on Agriculture. 
tion is inherently restricted both in terms of wording and interpretation apart from the inherent restriction that emanates from within.

In recent years, there were many unilateral measures that are said to be taken either as justified under Article XX of the GATT or as an enforcement of an MEA. In the normal course of events, those measures negatively affect goods and services originating in another member state and in some instances provoking disputes.

\section{The Major Cases Involving the GATT Article XX Exceptions}

There are various issues appearing before dispute settlement bodies. ${ }^{55}$ The basic features of the disputes are that state members to the GATT/WTO introduce or adopt a measure or policy meant for the protection of human, animal and plant life and health, and the environment. Other (victim) states complain that the policy/measure is contrary to the principles of GATT/WTO, those basic principles being the principle of Most-Favoured-Nation (MFN) treatment, national treatment, restriction to liberal trade or an introduction of quantitative restriction, or illegal measures and procedures. The state complained against usually attempts to justify its measures under GATT Article XX, the General Exception, and the provisions of the Agreement on TBT as in EC-Asbestos case. The following is a summary of major cases in this regard.

\section{1- The United States - Prohibition of Tuna and Tuna Products from Canada 56}

This is the first case that appeared before a dispute settlement body on the basis of the general exceptions of the GATT Article XX, although Article XX is raised as a post facto justification. On 31 August 1979, the US prohib-

55 The phrase the dispute settlement bodies in this case refers to the different institutions including both before and after the establishment of the WTO Dispute Settlement Body (DSB) in 1995. For instance, the first dispute that arose between the US and Canada on the former's prohibition of tuna and tuna products from Canada was initiated in 1981 and was submitted to conciliation.

56 In the discussion of trade and environment, particularly within the DSB, the US prohibition of tuna and tuna products imposed in 1979 is not mentioned per- haps because it is not primarily focused on the environment. Thus, it is the tuna case that was initiated by Mexico as discussed later that is referred to as Tuna I and the one initiated by the EEC and the Netherlands is referred to as Tuna II. Without breaching the custom of referring to the following two cases as Tuna I and Tuna II respectively, however, I find it necessary to include this case against the US prohibition of tuna and tuna products from Canada in my discussion as the first landmark in the trade-environment dispute. 
ited imports of tuna and tuna products from Canada. This action followed the seizure of 19 fishing vessels and the arrest by Canadian authorities of a number of United States fishermen, engaged in fishing for albacore tuna within 200 miles of the West Coast of Canada without authorization by the Canadian government, in waters regarded by Canada as being under its fisheries jurisdiction and regarded by the United States as being outside any state's tuna fisheries jurisdiction. ${ }^{57}$

The United States' prohibition was imposed pursuant to Section 205 (Import Prohibition) of the Fisheries Conservation and Management Act of 1976, which provide inter alia, that:

[I]f the Secretary of State determines that any fishing vessel of the United States, while fishing in waters beyond any foreign nation's territorial sea, to the extent that such sea was recognized by the United States, being seized by a foreign nation as a consequence of a claim of jurisdiction which was not recognized by the United States, the Secretary of Treasury should immediately take such action as may be necessary and appropriate to prohibit the importation of fish and fish products from the foreign fishery involved. ${ }^{58}$

Thus, since the United States does not recognize the Canadian claim to jurisdiction over tuna in waters where the vessels were seized, it took the action in accordance with the provisions of Section 205.59 It is both Section 205 and its consequential measures that are the subject of the dispute.

Canada submitted that the action taken by the US is discriminatory contrary to the principles of the GATT and impaired the benefits accruing to it under the GATT. ${ }^{60}$ It further contended that the measure is based on a domestic legislation in order to conform to the commercial interests of the powerful West Coast tuna fishery lobby ${ }^{61}$ while the United States maintained that it is fully justified under Article $\mathrm{XX}(\mathrm{g})$ of the GATT which provided an exemption from other GATT obligations for measures relating to conservation of exhaustible natural resources. ${ }^{62}$

\section{2- United States - Restriction on Imports of Tuna from Mexico (Tuna I)}

Tuna are commonly caught in commercial fisheries using large "purse seine" nets. ${ }^{63}$ In the eastern tropical Pacific Ocean, but not in other waters, schools 5758

\footnotetext{
57 United States - Prohibition of Tuna and ${ }^{59} \mathrm{Id}$. para 2.3

Tuna Products from Canada (Tuna I), $60 \mathrm{Id}$. para 3.1

Report of the Panel (L/5198 - 29S/91) ${ }^{61} \mathrm{Id}$. para 3.4
adopted on 22 February 1982 , para 2.1

${ }^{58} \mathrm{Id}$. para 2.2

${ }^{62} \mathrm{Id}$. para 3.5
} 
of tuna often swim below herds of dolphin that are visible swimming at or near the surface. Tuna fishermen in the eastern tropical Pacific therefore commonly use dolphins to locate schools of tuna, and encircle them intentionally with purse seine nets on the expectation that tuna will be found below the dolphins. ${ }^{63} 64$ The US Marine Mammals Protection Act of 1972 (MMPA) as amended, ${ }^{65}$ thus prohibits "taking" of and importation to the United States marine mammals save where an exception is explicitly authorized with a view to reducing incidental injury and killing to marine mammals in the course of commercial fishing: 66

The Secretary of Treasury shall ban the importation of commercial fish or products from fish which have been caught with commercial fishing technology which results in the incidental kill or incidental serious injury of ocean mammals in excess of United States standards.

This prohibition is mandatory. ${ }^{67}$ The relevant provision, Section 101(a) (2) (B) bans the importation of yellowfin tuna harvested with purse-seine nets in the ETP and products therefrom unless the Secretary of Commerce finds that the government of the harvesting country demonstrated that it has "(1) implemented a dolphin protection program 'comparable' to that of the US fleet," and "(2) achieved an incidental dolphin kill rate comparable 68 to the US fleet." ${ }^{9}$ In 1990 (and more stringently in 1991) the US banned import of tuna and tuna products from Mexico directly and later, also import through intermediary nations. ${ }^{70}$ It is both these rules and the measure that are the subject of the dispute. Mexico contended that section 101(a) (2) is inconsistent with GATT Article XT and section 101(a) (2) (B) is contrary to GATT Art. XTTT. ${ }^{71}$

63 Tn this process of catching tuna fish, a fishing vessel using this method sends a small boat carrying one end of the net around a school of tuna. The other end of the net remains attached to the fishing vessel. Once the boat has encircled the school of tuna and returned its end of the net to the vessel, the vessel winches in cables at the bottom and the top of the net, thus "pursing" it and gathering its contents. Tuna $\mathrm{H}$ infra para 2.1

64 Tuna T para 2.2

65 The amendment is with a view to give more competitive disadvantage to the US fleet, thus to address the practice of other nations more effectively.

66 Tuna TT, para 2.3
66 Tuna TT, para 2.3

$67 \mathrm{Id}$. para 2.5

68 After the 1991 amendment, in order for an average incidental dolphin mortality rate to be considered "comparable" it may not exceed 1.25 times the average US vessels for the same period. Tn addition, the share of eastern spinner dolphin and coastal spotted dolphins may not exceed fifteen percent and two percent respectively, of the total number of dolphins taken. $I d$. para 2.4

Id. para 2.5; it is also provided that the burden of proof is on the country who introduced the measure. $I d$.

${ }^{70} \mathrm{Id}$. para 5.5

${ }^{71} \mathrm{Id}$. para 3.1 
The US, on the other hand, maintained that it is a domestic measure consistent with Article III, and should the Panel fail to accept this argument, it is justified under GATT Article XX.72

\section{3- USA: Restrictions on Imports of Tuna (Tuna II)}

The facts of this case are identical to Tuna I that the EC and the Netherlands challenged the measures taken by the US ban of importation of tuna produced by a method that resulted in the incidental kill or serious injury of marine mammals in excess of the United States standard..$^{73}$ The subject of the dispute was whether the MMPA and the consequent measure by the US government is quantitative restriction within the meaning of Articles XI and III. ${ }^{74}$

The EEC and the Netherlands challenged the measure on the ground that:

Article $\mathrm{XX}(\mathrm{g})$ or (b) could not be invoked in this case to conserve natural resources or to protect the life or health of living things located outside the jurisdiction of the party taking the measure. Although the text of these paragraphs did not explicitly restrict the location of the resource or living thing to be protected, this did not mean that such a limitation was not contained in the provision.

The EC also objected to the measure on the ground that it focuses on the production technique, ${ }^{75}$ and this position was supported by third parties. ${ }^{76}$

\section{4- The U.S. - Gasoline Case}

The US Congress enacted the Clean Air Act in 1963 intended to prevent and control air pollution in the United States. ${ }^{77}$ By an amendment in 1990, the US

72 This is a landmark case on environmental disputes in the GATT system and its significance lies in that it raised the issue of Production Process Method (PPM) and made a distinction between the product and the production process which is also supported by third parties. Mexico touched upon it not incidentally, while Australia and Canada made it their principal argument $I d$. paras 4.2 and 4.8 respectively. For detailed discussion see R. Hudec "GATT/WTO Constraints on National Regulations: Requirements for an Aim and Effects Test".

${ }^{73}$ Report of the Panel, United States - Restriction of Imports of Tuna (Tuna II) (16 June 1994) para 2.9; with respect to the imported yellowfin tuna harvested with purse seine nets in the eastern tropical Pacific, however, the government of the harvesting nation must meet a number of specific conditions. The requirements of those conditions are discussed in Tuna I.

${ }^{74} \mathrm{Id}$. para 3.93

${ }^{75} \mathrm{Id}$. para 3.59

76 Both Australia and Venezuela made this argument $I d$. paras $4.4,4.6$ and 4.44 . Australia, in another submission to the EMIT on the topic GATT and the International Environmental Agreements (10 October 1993) objected to the extrajurisdictional arguments when such measure is taken based on multilateral environmental agreement para 31.

77 The Clean Air Act of 1990 
Environmental Protection Agency (EPA) is authorized to issue Regulations to implement the Clean Air Act, applied to the US refiners, blender and importers of gasoline ${ }^{78}$ based on the composition and emission effects of gasoline. 79

Accordingly, the EPA issued Regulations that provide for compositional and performance specifications for both types of gasoline set in comparison to certain baseline figures which is called Gasoline Rule. The Rule certainly makes distinction between importers and domestic refiners 80 in establishing quality baseline and is thus the subject of this dispute. ${ }^{81}$ *

\section{5- The U.S.- Shrimp/Turtle Case}

Currently, there are seven types of sea turtles recognized. These sea turtles are affected by activities of man either directly (for their meat, shell and eggs) or indirectly (by incidental capture, destruction of their habitat or pollution of the ocean). All sea turtles are considered to be endangered and thus found listed in Appendix T of the 1973 Convention on International Trade in Endangered Species ("CITES"). ${ }^{83}$ Thus, the US Congress passed Section 609

78 Panel Report, United States - Standards for Reformulated and Conventional Gasoline (29 January 1996) para 2.1

79 Section $211(\mathrm{k})$ of the Act divided the market for sale of gasoline into two: areas of the United States experiencing the worst ozone pollution where only reformulated gasoline could be sold to consumers and the rest of the United States where conventional gasoline may be sold. $I d$. para 2.2

80 According to the US, by August 1995 only 100 US refiners representing $98.5 \%$ of the gasoline produced in 1990 had received EPA approval of their individual baseline and only 3 of those refiners met the statutory baseline for all parameters. Importers, on the other hand, were generally required to met the higher statutory baseline.

81 The rule sets both historical and statutory baselines. Thus, with respect to determining a domestic refiner's individual historic baseline, the Rule established three methods: "Under Method 1, the refiner had to use the quality data and volume records of its 1990 gasoline. If Method 1 type data were not available, a domestic refiner had to use its 1990 gasoline blendstock quality data and 1990 blendstock production records, Method 2. In the event that neither of these two methods was available, a domestic refiner had to turn to Method 3 type data, which consisted of its post-1990 gasoline blendstock and/or gasoline quality data modeled in light of refinery changes to show 1990 gasoline composition.

On the other hand, certain entities were automatically assigned the statutory baseline. First, refineries which began operation after 1990 or were in operation for less than 6 months in 1990 were required to use the statutory baseline. Second, importers and blenders were assigned the statutory baseline unless they could establish their individual baseline following Method 1. Moreover, if actual 1990 data were not available, importers and blenders were assigned to the statutory baseline."

${ }^{82}$ Report of The Panel U.S. - Import Prohibition of Certain Shrimp and Shrimp Products (15 May 1998) para 2.3 
of Public Law 101 - 162 enacted in 1989 ("Section 609") on the basis of which US Government introduced a Guidelines requiring the use of Turtle Excluder Devise ("TED") developed by the US National Marine Fisheries Services, in fishing shrimp. ${ }^{83} 84$

Section 609 provides, ${ }^{85}$ among others, that shrimp harvested with technology that may adversely affect certain sea turtles protected under US law may not be imported into the United States, unless the importing nation is certified that its fishing environment does not pose a threat of incidental taking of sea turtles in the course of commercial fishing ${ }^{86}$ or that it has a regulatory program governing the incidental taking of such sea turtles in the course of such harvesting that is comparable to that of the United States, that the average rate of that incidental taking by the vessels of the harvesting country is comparable to the average rate of incidental taking of sea turtles by United States

83 “According to the US Endangered Species Act, 1973, all sea turtles are endangered or threatened species. Also research programs undertaken in the Gulf of Mexico and the Atlantic Ocean off the southeastern United States led to the conclusion that incidental capture and drowning of sea turtles by shrimp trawlers was the most significant source of mortality for sea turtles." National Research Council, National Academy of Sciences, (1990), Decline of the Sea Turtles: Causes and Prevention, Washington D.C., as cited in Shrimp/Turtle case paras $2.1-2.3$

${ }^{84} I d$. para 2.5. A TED is grid trapdoor installed inside a trawling net that allows shrimp to pass to the back of the net while directing sea turtles and other unintentionally caught large objects out of the net.

85 The section has three elements: first, it requires the US State Department to commence negotiations for bilateral and multilateral agreements to protect sea turtles; second, it requires the State Department to report to Congress within a year on the practice of other countries affecting the mortality of sea turtles; and third, it prohibited the importation of any shrimp harvested using commercial fish- ing technologies that might harm sea turtles, unless exporting countries are certified by the US administration as having a regulatory program to prevent incidental turtle deaths comparable to that of the United States or is certified as having a fishing environment that does not pose risks to sea turtles from shrimping. R. Howse "The Appellate Body Ruling in the Shrimp/Turtle Case: A New Legal Baseline for the Trade and Environment Debate" in 27 Colum. J. Envtl. L. (2002) p 3

86 The 1996 Guidelines define shrimp or shrimp products harvested in conditions that does not affect sea turtles to include: "(a) Shrimp harvested in an aquaculture facility ...; (b) Shrimp harvested by commercial shrimp trawl vessels using TEDs comparable in effectiveness to those required in the United States; (c) Shrimp harvested exclusively by means that do not involve the retrieval of fishing nets by mechanical devices or by vessels using gear that, in accordance with the US programme ... would not require TEDs; (d) Species of shrimp, such as the pandalid species, harvested in areas in which sea turtles do not occur." Id. paras 2.12, 2.13. The standard is identical to that of Section 609 (b) (2) (C). 
vessels in the course of such harvesting. ${ }^{87}$ The certification is to be made annually thereafter. ${ }^{88}$

Both the 1991 and the 1993 Guidelines (the original and the revised Guidelines, respectively) were meant to apply to certain Caribbean/western Atlantic countries. ${ }^{89}$ But later, the Court of International Trade, on an action brought by Non-Governmental Organizations (NGOs), ruled that Section 609 is applicable to any country where shrimp harvesting may adversely affect those species of sea turtles ${ }^{90}$ which resulted in the Guidelines $1996 .{ }^{91}$

The subjects of the dispute are both Section 609 and the 1996 Guidelines. The complaints were that the US measure constitutes a prohibition or restriction on the importation of shrimp or shrimp products in violation of GATT Article XI. ${ }^{92}$

\section{6- The Brazil - Retreated Tyre Case}

The dispute was between Brazil and the EC concerning various measures taken by Brazil relating to importation of retreated tyres. ${ }^{93}$ The complaint was basically (a) on the prohibition of import license for retreated tyres; (b) banning the importation of used tyres; (c) imposition of fine on the importation of retreated tyres as well as on the marketing, transportation, storage, ...or warehouses of imported, but not domestic, retreated tyres; (d) in some states of Brazil, restricting sale of imported retreated tyres and sale of retreated tyres made in Brazil from imported castings; (e) exemption from import ban for retreated tyres imported from MERCOSUR countries based on ruling of MERCOSUR tribunal and the Brazilian court suspending the ban and held that they are not capricious and unpredictable. ${ }^{94}$

The EC claimed violation of the GATT Articles I:1, III:4, XI:1 and XIII: 1 while Brazil argues such measures were justified under GATT Articles XX (b) and XX(d), and that the exemption for MERCOSUR countries was justified under GATT Article XXIV. It was each measure that became the subject of the dispute in this case.

${ }^{87} I d$. para 2.14

${ }^{88}$ Id. para 2.14

${ }^{89} \mathrm{Id}$. para 2.9

${ }^{90} \mathrm{Id}$. para 2.15

${ }^{91} \mathrm{Id}$. paras $2.10-2.11$

92 Id. para 7.11; GATT Art XI: 1 (General Elimination of Quantitative Restrictions) provides that "No prohibitions or restrictions other than duties, taxes or other charges, whether made effective through quotas, import or export licences or other measures, shall be instituted or maintained by any contracting party on the importation of any product of the territory of any other contracting party or on the exportation or sale for export of any product destined for the territory of any other contracting party."

${ }^{93}$ Panel Report Brazil - Measures Affecting Imports of Retreated Tyres (12 June 2007) paras $2.1-2.4$

${ }^{94} \mathrm{Id}$. paras $2.7-2.16$ 


\section{Interpretation of GATT Article XX and its Relations with MEAs}

As it has been alluded earlier, measures relating to the protection of human, animal and plant life and health and exhaustible natural resources are trade related and, thus, they seem to be deviations from the basic obligations envisaged during the creation of the GATT. In addressing such measures within the context of trade, there are three outstanding issues that have evolved through time - the sequence of interpretation of the provisions of Article XX, its scope and its relation with MEAs.

\section{1- Sequence of interpretation}

It is indicated in the summary of the cases that the measures that are taken by a state are challenged on the ground that they are contrary to the principles of the GATT, i.e. non-discrimination contrary to the principles of MFN and National Treatment, as well as restriction to international trade. Those states (complained against) on their part are raising the defence that the measures are not contrary to the GATT principles, and should they be found to be contrary to the GATT principles, they are justified under GATT Article XX, and that the measures are taken with a view to protecting human, animal and plant life and health, the environment or with a view to protecting an exhaustible natural resource. ${ }^{95}$

In these disputes, a pattern of interpretation of the content of GATT Article $\mathrm{XX}$ has evolved. In the US-Canada tuna case, the US representative discussed the provisions of Article XX in his argument. However, as the measure is found to be contrary to other GATT principles, the Panel did not rule on Article XX. The important case in this regard is the Tuna I, where an elaborate argument was made on the content of Article XX, the Panel held that the US measure is not justified under both paragraphs (b) and (g) of Article XX by analyzing the contents of both the chapeau and the paragraphs together. ${ }^{96}$

The analysis of trade - environment issues is properly addressed in Tuna II for the first time. The Panel followed three - step analysis for both paragraphs: first, whether the policy invoked falls within the range of policy sought under Article XX; second, whether the measure is taken within the

95 In the Canada Tuna case, there was no disagreement that dolphins are exhaustible natural resources, but later it is adopted that they are actually natural resources. In the US-Gasoline case, air held to be exhaustible natural resource; generally the meaning of exhaustible natural resource has been modified significantly in the course of those cases. 96 Paras 5.29 \& 5.34, respectively 
context of the challenged policy along with other similar domestic measures (on production/consumption of the said good) to address the issue; and third, whether the measure complies with the requirements of the chapeau of Article XX. ${ }^{97}$

In the first case, the Panel addressed the sequence of examination of the order of the requirements under GATT Article XX. In Tuna II, the Panel, in its three-step analysis rationally followed a certain order as indicated above. The order of examination of the requirements of Article XX is made clear in the US-Gasoline case for the first time. In that case, the Panel decided that the measures are contrary to the principles stated in the chapeau. This made the determination whether it falls under any of the exceptions listed under paragraphs (a) to (j) unnecessary. ${ }^{98}$ On appeal, the Appellate Body ("the AB") reviewed first whether the measure falls under any of the listed exceptions and it held that it falls under Article $\mathrm{XX}(\mathrm{g})$. The $\mathrm{AB}$ further examined whether the measure fulfils the requirements of the chapeau. The AB thereby reversed the sequence of examination of the provisions of Article XX. ${ }^{99}$

Although the Appellate Body (AB) had already delivered its decision on the Gasoline case, the Panel in the US-Shrimp/Turtle case, failed to comply with the order of interpretation of the provisions of Article XX. In subsequent cases, the Panel first addressed the issue whether the measure taken by the US fulfils the requirements of the chapeau, which it found in the negative, ${ }^{100}$ after which it stated that it is unnecessary to examine whether such measure falls under any of the listed exceptions. ${ }^{101}$ In this case, the AB held that the Panel erred in the interpretation of the provision by failing to properly follow the sequence of steps, as are followed in the US - Gasoline case. ${ }^{102}$ In subsequent cases where there is a dispute whether a given measure is taken with a view to exercising the power under Article XX, the Panel first determined whether the said measure falls under any of the listed categories in paragraphs (a) to (j) before it examined whether it fulfils the requirements of chapeau of Article XX. That was the case both in the EC - Asbestos and the Brazil - Retreated tyre cases.

\section{2- Scope of Article XX}

As the provisions of GATT Article XX do not contain the word environment, the scope of Article has been a matter of dispute between member states and a matter of concern for environmentalists. Thus, parallel to the determination

97 Tuna II pp 49, 53

98 See paras 6.33, 6.34 and paras $6.40,6.41$ for paragraph (d) and (g) of Art XX, respectively.
${ }^{99}$ P 23

100 Paras 7.48 and 7.49

${ }^{101}$ Para 7.63

102 Para 122 
of the sequence of steps in the interpretation of Article XX in the course of those disputes, the scope of Article XX is also determined. It is evident that a member state can adopt its own policy for the purpose of the protection of human, animal and plant life and health, and for conservation of exhaustible natural resources. ${ }^{103}$ A birds-eye-view of the cases indicates that the determination of whether a given measure falls under paragraph (a) to (j) is not as difficult as determining whether it fulfils the requirements of the chapeau of Article XX which are discussed at three levels:

i. The GATT is a trade agreement; but the purpose of Article XX is to ensure that GATT does not impede states to take such necessary measures to pursue their own public policy not necessarily in conformity with other GATT obligations. ${ }^{104}$ It has been observed by the Panel and the AB in the cases discussed above that there has to be a policy ${ }^{105}$ principally aimed ${ }^{106}$ at the protection of human, animal or plant life or health, or the protection of exhaustible natural resources on the basis of which the measure is taken.

ii. As a deviation from the basic principles of the GATT such measure might be found contrary to the principles of national treatment. 107 However, the chapeau prohibits that the measure cannot be applied "in a manner which would constitute a means of arbitrary or unjustifiable discrimination between countries where the same conditions prevailed." Such discrimination is not an ordinary discrimination which is prohibited under Article III, but one which is necessary to be justifiable under Article XX. ${ }^{108}$ Such measure should not be more restrictive than it is necessary to achieve a public policy goal as encompassed in Article XX. ${ }^{109}$ The inter-

103 Although it has not been directly addressed by the Panels for example in the case of Tuna I, it has been raised by both complaining states and third parties that the measure can be applied only within the national territory of that state (paras 4.1, 4.5, 5.27). It is also addressed by the EC in its submission to the GATT that such national measure is extra - jurisdictional in application EMIT The GATT and the Trade Provisions of the Multilateral Environmental Agreements Submissions by the European Community (17 November 1992) para 2.4

${ }^{104} I d$. para 2.4

105 Tuna II, para 5.12; US-Gasoline AB page 15
106 Tuna II, para 5.31; US - Gasoline pp 18, 19

107 It has been indicated by Schultz (Supra note 49 at 427) that there is no deviation from MFN. That is what is affirmed by the Panel in the Brazil - Tyre case.

108 What appears from the reading of those cases is that the nature of discrimination under Art XX is different from other discriminations that, Art III is on explicit discrimination to foreign goods and services, while that of Art XX is origin neutral nevertheless discriminate against foreign goods and services. This is also enunciated in Hudec Supra note 72 at 3

${ }^{109}$ Submission form the European Community, Supra note 42, para 2.5 
national standards as included in TBT and SPS Agreements, for example, are deemed to fulfil the necessity test. ${ }^{110} 111$

iii. The measure should not be used as a disguised restriction to international trade. There is little guidance in the GATT as well as in the cases regarding what constitutes "disguised restriction on international trade". The ordinary reading indicates that the objective or effect of the measure is to afford protection to domestic producers in circumstances where such protection is not necessary to achieve other legitimate objectives under Article XX.

\section{3- The relation between Article XX of GATT and ME A rules}

Tt is stating the obvious that the GATT and MEA rules are separate regimes. Some describe them as neither friends nor foes, but neighbours. ${ }^{\mathrm{m}}$ The GATT Secretariat in early days stated that while "many environmental measures are likely to have no significant effects on trade, those that do can have complex trade effects." 112 It also stated that in the absences of relevant information, "few generalizations can be made about the likelihood of any particular measure creating, diverting, or restricting trade."113

Environmental measures are applied in the form of pure border restrictions that would clearly restrict trade. However, most of the measures are internal measures, "such as taxes and charges or technical regulations and standards, which affect market access and the conditions of competition for all producers, both domestic and overseas." 114 The trade effects of such measures are

110 What are those products that are subject to restriction? Austria suggested that these are products which are not only themselves, or through the substances physically incorporated, environmentally damaging but also products on the basis that their production is damaging to the environment under certain circumstances. Group on Environmental Measures and International Trade Submission by Austria GATT AND TNTERNATONAL EVVIRONMETAL AGREEMENTS (IEAs) (1 October 1993) para 2.5

111 B. Krist "Nether friends Nor foes, But Neighbours: An Introduction to the Relationship between the WTO and MEAs" in Trade and Environment, the
WTO, and MEAs <www.boell.org> (last accessed December 6, 2007) p 1

112 Measures affecting trade based on MEAs are placed under three categories by the GATT Secretariat which are referred to as Models. The first model is based on export certificate and/or import permit; the second model is introducing local exceptions; and the third model is regulation of local production and consumption of goods, Secretariat Note 1 Supra n. 43, paras 5, 6, $17 \& 24$

113 Group on Environmental Measures and International Trade: THE TRADE EFFECTS OF ENVIRONMENTAL MEASURES" Note by the Secretariat (29 June 1993, hereinafter, GATT Secretariat Note IT) para 4 , 
hard to predict. ${ }^{115}$ That aside, there is still unsettled view regarding how far those measures taken based on the provisions of MEAs are accommodated under GATT Article XX.

Some governments made it clear that the two are so distinctive that the insertion of the word environment in Article XX does not remedy the ill because the focus on Article XX does not imply measures impacting on trade for environmental reason. This includes measures taken pursuant to a MEA, which necessarily constitute exceptions to GATT obligations. ${ }^{116}$ However, it is believed that the public policy objective sought under paragraphs (b) and (g) are broad enough to encompass environmental protection objectives. ${ }^{117}$ Others argue that if TBT and SPS allow member states to adopt international standard (that is not considered to be a disguised restriction to international trade). And the requirements should comply with MEAs as they are meant for establishing international standard. ${ }^{118}$ This argument doesn't seem to be convincing at least under circumstances where both state parties to a dispute are parties to the GATT and the complaining state is not a party to the MEA. That in turn begs the question whether those MEAs could modify the obligations under the GATT.

For all what it is worth, some individuals argue that based on the rules of treaty interpretation, the MEAs trump the GATT in so far as they came later, which unfortunately is not the case for many of them. ${ }^{119}$ That raises the question whether the DSB has jurisdiction. Equally, the power of dispute settle-

${ }_{114}^{114}$ Para 5

115 Many factors can affect the outcome. Those that would appear to warrant particular attention, according to the Secretariat are: "(i) policy-induced discrimination against overseas suppliers; (ii) lack of full and timely transparency for overseas suppliers. This is of particular importance in the case of voluntary measures, such as eco-labelling; (iii) market characteristics, such as size and openness to trade (a small market may dissuade overseas suppliers from undertaking product changes to maintain market share, a large market may encourage them to make the effort, and a market of global importance may cause changes in standards in other markets), proximity to overseas suppliers (long-distance suppliers may be particularly vulnerable to restrictions on product packaging), industry concentration, product substitutability and consumer preferences; (iv) which specific products the measures apply to; (v) environmental resource endowments and constraints among domestic and overseas suppliers; and (vi) the availability of technology needed to meet new product standards."

${ }^{116}$ EC Submission Supra note 42, para 2.4

${ }^{117} \mathrm{Id}$.

118 In Austria's Submission (Supra note 110) it is referred to as The primary purpose test para 44 Esq.

119 Austria in its submission to the GATT suggested to include a trumping clause to Art XX for future MEAs Ibid, paras 85 - 87 a view supported by Schultz Supra note 49 at 343. 
ment bodies is restricted and perhaps the only function of the WTO DSB is serving in preserving "the rights and obligations of Members under the covered agreements, and to clarify the existing provisions of those agreements. $" 120 * *$

The EC rather suggested a clarification and a set of standard of application of MEAs for a non-party state that:

a) a number of substantive criteria, based on the interpretation of Article $\mathrm{XX}$, which ensure that trade measures applied to non-participants do not go beyond what is necessary to achieve the environmental goals of the agreements;

b) certain formal criteria related to the concept of a multilateral environmental agreement, so as to ensure that the exception for the application of trade measures to non-participants is limited to cases in which environmental protection commitments have been established through a genuine multilateral process. ${ }^{1}$

120 The phrase covered agreements include (a) Agreement Establishing the World Trade Organization (b) Multilateral Trade Agreements: the Agreements on Trade in Goods, the General Agreement on Trade in Services, the Agreement on Trade-Related Aspects of Tntellectual Property Rights and the Understanding on Rules and Procedures Governing the Settlement of Disputes; (c) Plurilateral Trade Agreements: Agreement on Trade in Civil Aircraft, Agreement on Government Procurement, International Dairy Agreement and Tnternational Bovine Meat Agreement (Appendix 1, DSU) which does not cover MEAs. It is further provided that in the discharge of its responsibilities, the Panel is instructed to make an objective assessment of the matter before it, including an objective assessment of the facts of the case and the applicability of and conformity with the relevant covered agreements, an obligation by which the $A B$ is bound by. It is further provided that the recommendations and rulings of the DSB cannot add to or diminish the rights and obligations provided in the covered agreements. Art 3 (2) DSU; Art 11, Functions of the Panel (DSU)
121 Group on Environmental Measures and International Trade THE GATT AND the Trade Provisions of MultilatERAL ENVIRONMENTAL AGREEMENTS: Submission from The European Community 17 November 1992, Para 2.4. Austria on its part submitted that what is relevant, from the GATT perspective, is whether there is actual difference between the environmental protection commitments applied by parties and non -parties. This GATT requirement is indeed fully recognized under CITES, Basel and the Montreal Protocol which allow for trade with non-members to be carried out on the same basis as with members provided non-members apply equivalent environmental guarantees. It can be expected that any future Multilateral Environmental Agreement which envisages the application of trade measures to non-members would include similar provisions so as to avoid GATT inconsistencies. Moreover, clarifying the interpretation of this requirement would also provide an insurance against any possible abuse by the signatory of the MEA when implementing the Convention.

${ }^{122}$ Austria's submission, Supra note 110 
Some governments even reject objections based on the extra-territorial application of domestic environmental measures in so far are they are based on MEAs. ${ }^{122}$

\section{Concluding Observations}

it stands to reason that addressing environmental problems affect trade competitiveness; whether it is limiting emission of greenhouse gasses, transportation of hazardous waste, or preservation of biodiversity. The GATT Article $\mathrm{XX}$ is far too insufficient to properly address the issues of environment and WTo is not sufficiently competent to promote and enforce those issues in the world trading system.

Unfortunately, the efforts within the international community and the UN system are not promising in comparison to the magnitude of the problem. No state can point its finger on another because all states have environmental problems and each has its own share in taking the blame. There are environmental problems of the affluent and environmental problems of the poor. Needless-to-say, the earth is the common heritage of mankind and there has to be a systemic and concerted effort to address the problem at the national, regional and global levels with a view to mitigating further assaults against nature.

The majority of environmental problems occur within the national territories and can better be dealt with nationally as in the area of household energy consumption, combating deforestation or the use of efficient technology. it has been seen that GATT Article XX is not a barrier to the adoption of national policies and measures that are meant for the protection of human, animal and plant life and health, provided that it is not applied in a manner that amounts to be arbitrary or unjustified discrimination among states (where the same circumstance prevails), or if such measure is not implemented in a manner that restricts international trade. It is also observed that international standards as used in the TBT fall under this exception. Thus, it is possible to address environmental issues within the GATT system. The fact that the term environment is not included in this provision cannot be a restriction to the application of environmental measures in so far as they are meant for the protection of human, animal and plant life and health.

These policies and measures, however, need to focus exclusively on domestic matters, and should not be used as legal justifications for the restriction of international trade. In this regard, some recommend that the restriction of such measure to national territory is not justified and that like products 123

123 The word like products as was interpreted in the Japan's Liquor Tax Law case. 
need to be re-interpreted to accommodate product-process manufacture 124 with a view to avoiding free-riding. ${ }^{125}$ That might be considered an intellectual support to withdrawal from global free-trade in the guise of the basic principle called sovereign power of states.

Environmental problems beyond national territories can be addressed both at a regional and global level. It is true that environmental concerns of a given region are different from other regions. Regional environmental problems can be better addressed in regional systems. Thus, the immediate causes and effect of international environmental problems could be identified and analyzed more readily at the regional level ${ }^{126}$ based on the specific needs and conditions of the region.

As it stands now, the global framework seems to have pitfalls. The only unifying provision is GATT Article XX. Some states are parties to one MEA while some are parties to another. Certain MEAs are administered by UNEP, and many are not. GATT Article XX cannot replace MEAs nor is the relation between the two defined. In as much as it is expected to contribute its share in the protection of the environment, WTO is not thus the appropriate forum for the negotiation and enforcement of Multilateral Environmental Agreements (MEAs).

It is stating the obvious that, MEAs need to be administered under a unified relevant organ such as UNEP, and such organ need to have the power of enforcement and the resources at its disposal.

124 See Austria's Submission, Supra n.110; Schultz, Supra note 49 at 433; also WTO Public Forum 2007: "How can the WTO Harness Globalisation?" <www.wto.org> (last accessed October 19, 2007)
125 Can we then consider those who have been assaulting nature for the last more than a century were free-riders?

${ }^{126}$ Bishop and Munro, Supra note 1, p 349 


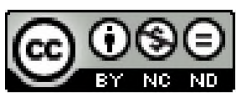

This work is licensed under a

Creative Commons

Attribution - Noncommercial - NoDerivs 4.0 License.

To view a copy of the license please see:

http://creativecommons.org/licenses/by-nc-nd/4.0/

This is a download from the BLDS Digital Library on OpenDocs

http://opendocs.ids.ac.uk/opendocs/ 